\title{
Return on Investment For Social Media: A Proposed Framework For Understanding, Implementing, And Measuring The Return
}

David M. Gilfoil, Ph.D., DeSales University, USA

Charles Jobs, Ph.D., DeSales University, USA

\begin{abstract}
Web 2.0 has enabled a whole new way for companies, user communities and others to engage each other. Social Media (SM) platforms (i.e. blogs, micro-blogs, social networks, video/photo upload sites), in particular, comprise a flourishing new set of eWOM and viral marketing mechanisms that are growing exponentially. More and more global companies are using SMsome because they know it works, others because they're afraid not to use it. How much they spend, and how long they continue to spend it, will depend on how effective SM proves to be in the long run. The measurement of social media effectiveness, or return on investment (ROI), is a key factor in the long term success of SM marketing and management programs. This paper provides a summary overview of the SM ROI literature where there is a vast range of opinions/models/calculations in both academic and trade journals. It suggests that the SM ROI issue is far more complex than most report, and provides a business "unit of analysis" framework for better understanding this complexity. It also discusses SM ROI measurement within the context of business process/performance management basics and suggests guidelines and principles for how and when to proceed with such measurement.
\end{abstract}

Keywords: eWOM; Viral Marketing; Web 2.0; Social Media Measurement; Social Broadcast Behaviors; Social Media ROI; Balanced Scorecard; Unit of Analysis

\section{INTRODUCTION}

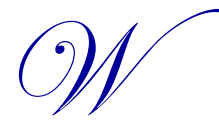

eb 2.0 has enabled a whole new way for companies, user communities and others to engage each other. Social Media (SM) platforms (i.e. blogs, micro-blogs, social networks, video/photo upload sites), in particular, comprise a flourishing new set of eWOM and viral marketing mechanisms that are growing exponentially. More and more global companies are using SM -some because they know it works, others because they're afraid they may suffer in the marketplace if they don't use it. How much they spend, and how long they continue to spend it, will depend on how effective SM proves to be in the long run. The measurement of SM effectiveness, or return on investment (ROI), is key. This paper provides a summary overview of the SM ROI literature where there is a vast range of opinions, models, and calculations in both academic and trade journals. It also suggests that the SM ROI issue is far more complex than most report, and provides a business "unit of analysis" framework for better understanding this complexity. It also discusses SM ROI measurement within the context of business process/performance management basics and suggests guidelines and principles for how and when to proceed with such measurement.

\section{METHODS}

This paper reviewed both the academic and industry literature pertaining to SM ROI measurement in search of a general direction or consensus on the topic. Significant summary positions were articulated in a conceptual factor analysis depicted in a set of five reasonably orthogonal views on the topic. 
A search was also conducted for a comprehensive, integrative framework or model for understanding the various views about how practically to address the issue of SM ROI measurement. Finally, a cursory review of the more basic literature on business process management and program/project design, implementation, and measurement was undertaken.

The ultimate deliverable of the paper is the integration of academic research and corporate/media publications into a practical 3-dimensional "unit of analysis" framework for understanding SM ROI complexity, along with key business process steps and guidelines for effective SM program design, implementation, and measurement.

\section{LITERATURE REVIEW}

With the advent of Web 2.0 in the last decade or so, there has been much interest in the development and usage of certain SM platforms. In particular, and of interest to the current authors, SM platforms have been studied because of their implications for global commerce (Piskorski and McCall, 2010; Van der Lans, Van Bruggen, Eliashberg, and Wierenga, 2010). Much literature exists, for example, in the usage of Web 2.0 and SM platforms in the marketing areas of electronic word of mouth advertising (Parise and Guianan, 2008; Jansen, Zhang, Sobel and Chowdry, 2009; Jalilvand, Esfanani, and Samiei, 2011) and viral marketing (Leskovec, Adamic, and Huberman, 2007; Hartline, Mirrokni, and Sundararajan, 2008). Constantinides, Romero, and Boria (2008), as well as Jobs (2011), and Gilfoil and Jobs (2011) have further studied the use of SM platforms for global buy and sell activities and have provided evidence of effective corporate use of SM platforms to engage user communities, prospects, and end customers in both active and passive ways. McKinsey (2010), in their annual survey of Web 2.0 technologies, describes a new "networked enterprise" that is emerging - one that uses Web 2.0 platforms extensively to connect internal efforts of employees and to reach externally to customers, partners, and suppliers. McKinsey data shows that fully networked enterprises are more likely to be market leaders and also more likely to have higher margins than companies using the Web in more traditional ways.

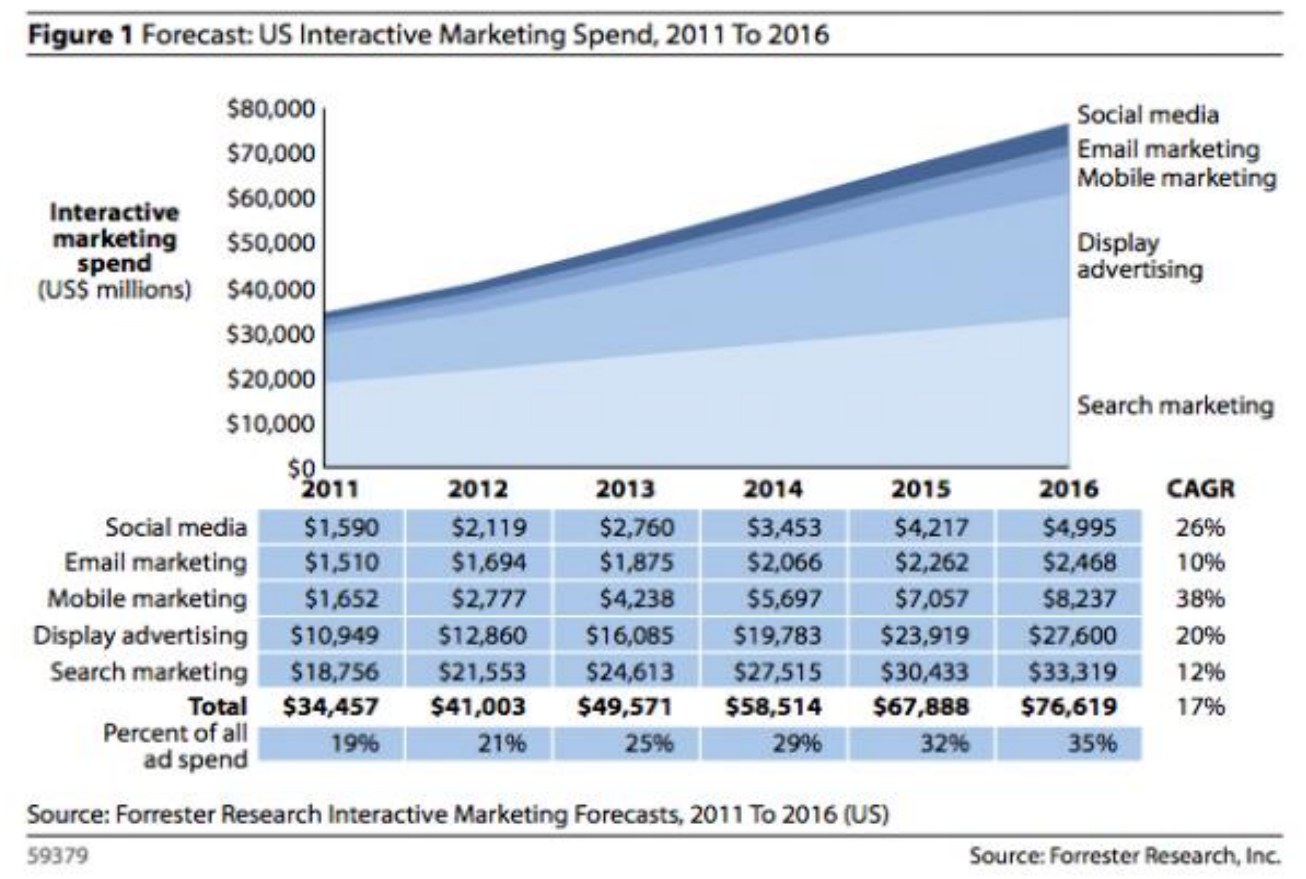

The trade media and professional publishers have also been quite busy extolling the virtues of blogging, micro-blogging, video blogging, social networking, and content aggregator platforms (Solis, 2008; Weber, 2009; Levy, 2010). At the same time however, they have been quick to point out that while SM marketing budgets have grown, they are still only a small fraction of total marketing spend, both in the U.S. and globally. Data from 
Forrester (2011) in Figure 1 shows that total projected interactive media spend in the U.S. ( \$77B) will only reach $35 \%$ of total marketing spend by 2016 - and SM spend ( $\$ 5 \mathrm{~B})$ is forecasted to be only about $6 \%$ of that interactive spend. The main reason for the lack of explosive growth (and significant real world marketing spend), is due to the simple fact that those in charge of the marketing purse-strings, have not yet been thoroughly convinced of the economic value of social media. Put another way, they have not yet seen the return on investment (ROI) of their SM spend.

To add to this lack of "put your money where your mouth is" conviction (financial commitment) by the finance (business) community, marketers, themselves, have not been convinced of the effectiveness of their SM strategies. A 2010 study conducted by Smartbrief reports that "of the 6000+ executives surveyed, only $14.2 \%$ of businesses find their social-media strategies to be "very effective" - and only $7.3 \%$ consider them "very revenue generating." Getting the ROI measurement piece right can only help shore up this lack of conviction.

\section{Return on Social Media Investment}

Return on investment (ROI) simply refers to the idea that something of value has resulted from an investment of time, energy, or money. In financial circles ROI usually is reduced to a formula (i.e. Lenskold, 2003; Bragg, 2006):

$$
\text { ROI }=\frac{\text { (Gain from Investment }- \text { Cost of Investment) }}{\text { Cost of Investment }}
$$

ROI is calculated by simply subtracting the cost of an investment from the proceeds received from the investment, divided by that same investment cost. If, for example you sell a product for $\$ 150$, and the total cost is only $\$ 120$ for the item, then your ROI is (150-120)/120 or $25 \%$.

ROI of SM has been very widely discussed and debated in trade publications, corporate and consumer blogs, and a host of professional publications (Bartholomew, 2009, 2010; Fisher, 2009; Murdough, 2009; Arnold, 2011; Nair, 2011; Ray, 2010; Solis, 2010). Several books have even emerged on the topic (i.e. Blanchard, 2011; Powell, Groves, Dimos, 2011). Research can best be summarized by the following range of views:

1. $\quad$ SM ROI cannot be measured; attempts to do so are folly or near impossible

2. $\quad$ SM ROI can be measured - but should be defined or specified in a certain way

3. $\quad$ SM ROI can be measured - but only in financial terms

4. $\quad$ SM ROI can be measured - but should be part of a larger, contextual framework or system

5. SM ROI can readily be measured without much difficulty

Table 1 shows more details of these summary views. While the views - and reviews of those views - see Fisher (2009), Broom, McCann, Bromby, and Barlow (2011), Dorflinger (2012) - are varied, it is clear that the issues are complex. If we are to make systematic headway in demonstrating a pervasive "value add" for SM project investments, we must look at them in the proper context.

What is clear from a review of the relevant work depicted in Table 1 is that nothing much is clear. What is needed is a more complete framework for understanding, implementing, and measuring the success of the (still evolving) SM playing field and a comprehensive set of business rules and guidelines for impactful stakeholder engagement.

Relative to SM ROI measurement, we need to understand what it is and what it is not, what the business context or unit under consideration is, what functions or activities are being measured, and what is the relative direct or indirect nature of the measurement under consideration. This body of work is an attempt to develop such a framework. 
Table 1: Summary Assessment Of Social Media ROI Position

\begin{tabular}{|c|c|c|}
\hline Position/View & Author/(Publication) & Comments \\
\hline \multirow{3}{*}{$\begin{array}{l}\text { 1. SM ROI cannot be } \\
\text { measured or is nearly } \\
\text { impossible (attempts to } \\
\text { measure are folly or will be } \\
\text { fraught with major issues) }\end{array}$} & $\begin{array}{l}\text { Zheng, et al (2010)/ } \\
\text { (Journal Article) }\end{array}$ & $\begin{array}{l}\text { - Zheng, et al. discuss the difficult challenges and modeling difficulties of "SM } \\
\text { analytics" and "social intelligence measurement" }\end{array}$ \\
\hline & $\begin{array}{l}\text { Filisko (2011)/ } \\
\text { (Journal Article) }\end{array}$ & $\begin{array}{l}\text { - Filisko argues that SM is about building relationships and making connections } \\
\text { to facilitate business. Measuring statistics is likely a meaningless exercise. }\end{array}$ \\
\hline & $\begin{array}{l}\text { Dorflinger (2011)/ } \\
\text { (DiplomaThesis) }\end{array}$ & $\begin{array}{l}\text { - Dorflinger provides a very comprehensive review of ROI arguments but } \\
\text { warns "How can companies measure the ROI of social media? The first step is } \\
\text { to accept that it is not really possible to do so" (p.57) }\end{array}$ \\
\hline \multirow{3}{*}{$\begin{array}{l}\text { 2. SM ROI can be measured - } \\
\text { but should be defined, } \\
\text { measured in a certain way }\end{array}$} & $\begin{array}{l}\text { Mangiuc (2009)/ } \\
\text { (Journal Article) }\end{array}$ & $\begin{array}{l}\text { - Mangiuc discusses a model, based on classic ROI computation methods - } \\
\text { measures detailed costs as well as "hard" \& "soft" benefits. }\end{array}$ \\
\hline & $\begin{array}{l}\text { Hoffman and Fodor } \\
(2010) / \\
\text { (Journal Article) }\end{array}$ & $\begin{array}{l}\text { - The authors suggest that "effective social media measurement should start by } \\
\text { turning the traditional ROI approach on its head. That is, instead of } \\
\text { emphasizing their own marketing investments and calculating the returns in } \\
\text { terms of customer response, managers should begin by considering consumer } \\
\text { motivations to use social media and then measure the social media } \\
\text { investments customers make as they engage with the marketers' brands." }\end{array}$ \\
\hline & $\begin{array}{l}\text { Pooja, et al., (2012)/ } \\
\text { (Journal Article) }\end{array}$ & $\begin{array}{l}\text { - Some Indirect SM measures can be used to ultimately impact financial ROI } \\
\text { (purchasing behavior); measures Customer Lifetime Value (CLV). }\end{array}$ \\
\hline \multirow[t]{3}{*}{$\begin{array}{l}\text { 3. SM ROI can be measured-- } \\
\text { but only in financial terms }\end{array}$} & $\begin{array}{l}\text { Turner }(2010) / \\
(B \log )\end{array}$ & $\begin{array}{l}\text { - Argues that SM can be broken down into quantitative, qualitative and ROI } \\
\text { metrics but must also consider CLV. Turner stresses that all measures must } \\
\text { ultimately lead prospects back to your website to convert into paying } \\
\text { customers. }\end{array}$ \\
\hline & $\begin{array}{l}\text { Blanchard (2009)/ } \\
\text { (Business Article) }\end{array}$ & $\begin{array}{l}\text { - Blanchard argues that ROI is a business, financial metric (\$ return vs \$ spent); } \\
\text { measurement of SM requires some way to translate the less tangible outcomes } \\
\text { of using SM into data that has meaning. Investment } \rightarrow \text { Action } \rightarrow \text { Reaction } \rightarrow \\
\text { Non-Financial Impact } \rightarrow \text { Financial Impact. }\end{array}$ \\
\hline & $\begin{array}{l}\text { Kaske, Kugler, and } \\
\text { Smolnik (2012)/ } \\
\text { (Conference Paper) }\end{array}$ & $\begin{array}{l}\text { - Authors present an "extended" financial ROI model that incorporates longer } \\
\text { term marketing and CLV concepts into a financial ROI formula. }\end{array}$ \\
\hline \multirow{5}{*}{$\begin{array}{l}\text { 4. SM ROI can be measured-- } \\
\text { but should be part of a larger, } \\
\text { contextual framework or } \\
\text { system }\end{array}$} & $\begin{array}{l}\text { Murdough (2009)/ } \\
\text { (Journal Article) }\end{array}$ & $\begin{array}{l}\text { - Murdough presents a five stage SM measurement process: concept, definition, } \\
\text { design, deployment, optimization - that should be based on how a brand } \\
\text { wants to engage with customers. }\end{array}$ \\
\hline & $\begin{array}{l}\text { Ray }(2010) / \\
(B \log )\end{array}$ & $\begin{array}{l}\text { - Ray defines and discusses an effective SM Balanced Scorecard including } \\
\text { financial, brand, risk management and digital metrics that cover short and } \\
\text { long term as well as financial and non-financial items }\end{array}$ \\
\hline & $\begin{array}{l}\text { Nair }(2011) / \\
\text { (Journal Article) }\end{array}$ & $\begin{array}{l}\text { - Nair recommends the adoption of a SM Balanced Scorecard - to incorporate a } \\
\text { strategic approach and tactical implementation of SM projects; Nair } \\
\text { provides a healthcare case study to illustrate monitoring, managing and } \\
\text { measurement of SM efforts. }\end{array}$ \\
\hline & $\begin{array}{l}\text { Bartholomew (2011)/ } \\
\text { (Business Article) }\end{array}$ & $\begin{array}{l}\text { - Before selecting which SM tools to use, thought should be given to what } \\
\text { exactly you are measuring. Measurable objectives should be written which are } \\
\text { aligned with higher order goals, and key business processes should be } \\
\text { understood before metrics can be established. }\end{array}$ \\
\hline & $\begin{array}{l}\text { Blanchard (2011)/ } \\
\text { (Book) }\end{array}$ & $\begin{array}{l}\text { - Blanchard discusses best practices for strategy, planning, execution, } \\
\text { measurement, analysis, and optimization of SM programs. He defines how } \\
\text { financial and nonfinancial metrics are related. }\end{array}$ \\
\hline \multirow[t]{4}{*}{$\begin{array}{l}\text { 5. SM ROI can be readily be } \\
\text { measured }\end{array}$} & $\begin{array}{l}\text { Bughin and Chui (2010)/ } \\
\text { (Corporate Report) }\end{array}$ & $\begin{array}{l}\text { - Authors report on results of McKinsey survey which shows that use of Web } \\
2.0 \text { (including SM platforms) significantly improves companies' reported } \\
\text { performance. Authors suggest that fully networked enterprises have better } \\
\text { ROI - are more likely to be market leaders, gain market share, have higher } \\
\text { margins. }\end{array}$ \\
\hline & $\begin{array}{l}\text { Gillin (2010)/ } \\
\text { (Business Article) }\end{array}$ & $\begin{array}{l}\text { - Gillin cites that the internet is the "most measureable medium ever invented'. } \\
\text { Argues that most corporations don't understand the value of a customer or } \\
\text { even understand what they measure. Gillin provides calculations to see how } \\
\text { easy ROI calculation can be. }\end{array}$ \\
\hline & $\begin{array}{l}\text { Campbell, (2011)/ } \\
\text { (Blog) }\end{array}$ & $\begin{array}{l}\text { - Campbell identifies and describes features and benefits of the best tools } \\
\text { available to measure ROI of SM. }\end{array}$ \\
\hline & $\begin{array}{l}\text { Hall \& Hume (2011)/ } \\
\text { (Journal Article) }\end{array}$ & $\begin{array}{l}\text { - The authors suggest a six step, unobtrusive evaluation approach for measuring } \\
\text { ROI of SM and other digital marketing programs. }\end{array}$ \\
\hline
\end{tabular}




\section{PROPOSAL - 3D UNIT OF ANALYSIS FRAMEWORK \& IMPLEMENTATION GUIDELINES}

The purpose of this paper is to propose a broader approach to understanding how to measure the effectiveness of SM campaigns and projects. While several researchers and experts have identified/discussed key elements from a complex set of ROI measurement issues such as direct and indirect measures (i.e. Mangiuc, 2009), short vs. long term impact (i.e. Pooja, et al., 2012), financial vs. non-financial indicators (i.e. Blanchard, 2009), need for a SM balanced scorecard approach (i.e. Nair, 2011), a comprehensive, business approach to conceiving, executing and measuring SM program effectiveness has not been forthcoming in the academic literature. To truly understand the current state of SM ROI measurement issues, the authors' view is that three things must be addressed:

1. A conceptual framework for understanding that SM measurement can be established at multiple levels in the corporation, across (and in) various business functions, and can take a wide range of forms - most of which are not (immediately) measurable in financial ROI terms.

2. A clearly articulated set of business processes for establishing, rolling out, tracking, and adjusting SM initiatives.

3. A set of SM program implementation guidelines and principles to follow.

\section{Conceptual Framework}

As noted above, some SM researchers and gurus have begun to move us in the right direction - by demonstrating an understanding that SM programs/projects are complex and play out at various levels inside and out of the corporation as program managers engage customers, suppliers, employees and a host of other business stakeholders. They have done so in their suggested utilization of a "SM balanced scorecard" framework borrowing from the seminal work of Kaplan and Norton (1992, 1996, 2001), and others (Pearson, 2010; Sheridan, 2010) - "to articulate and manage (social media) strategy and make it operational" (Nair, 2010). They have also, in so doing, built upon the stakeholder analysis approach to strategic management as originated, and popularized, by Freeman (1984) and others (Freeman and Gilbert, 1987; Freeman and Evan, 1990).

What is needed, however, to get us closer to the SM ROI measurement holy grail, is to fully address what has been called, in business research methodology publications, the "unit of analysis" issue. Unit of analysis simply refers to the articulation of the specific entity that is being studied in a particular research endeavor (see Zikmund, et al (2010) and Trochim (2001)). Unit of analysis is important here because so much of the complexity and confusion in the SM ROI literature is caused by a lack of clarification around this issue.

Our proposed model (shown in Figure 2) attempts to address this unit of analysis complexity. In order for any business endeavor to be successful, whether the endeavor is a rollout of an annual corporate strategic plan, a strategic marketing plan, a sales plan involving revenue goal setting, or an advertising campaign, one must address the simple fact that there are typically levels of organizational complexity involved. And so it is with SM. The left side of the 3D cube in Figure 2 shows that SM campaigns, initiatives, or projects can be launched at several levels...from outside the company at an industry level (i.e. "got milk?") or at a corporate level (i.e. "We bring good things to life"). From within the corporation, we can also clearly see that SM projects or programs can be driven/managed by specific SBUs (i.e. Zappos footwear@twitter.com), departments (i.e. HR recruiting - "Be all that you can be") or even at an individual level (i.e. Sun CEO Jonathan Schwartz tweets his resignation - see NY Times, 2010).

The model also incorporates the idea that there can be a functional overlay with respect to SM initiatives the second dimension of our 3D framework. This is depicted in the front face of the 3D cube in Figure 2. Typical functions that might be heavily involved in SM initiatives are sales, customer service, business development, logistics, and research and development - although there are many more on a continuously growing list. SM researchers have recently enumerated many examples at these functional levels (i.e. Culnan, McHugh, and Zubillaga (2010); Gallaugher and Ransbotham, 2010; Gangi, Wasko, and Hooker, (2010). 
Figure 2: 3d Unit Of Analysis Framework For Social Media ROI

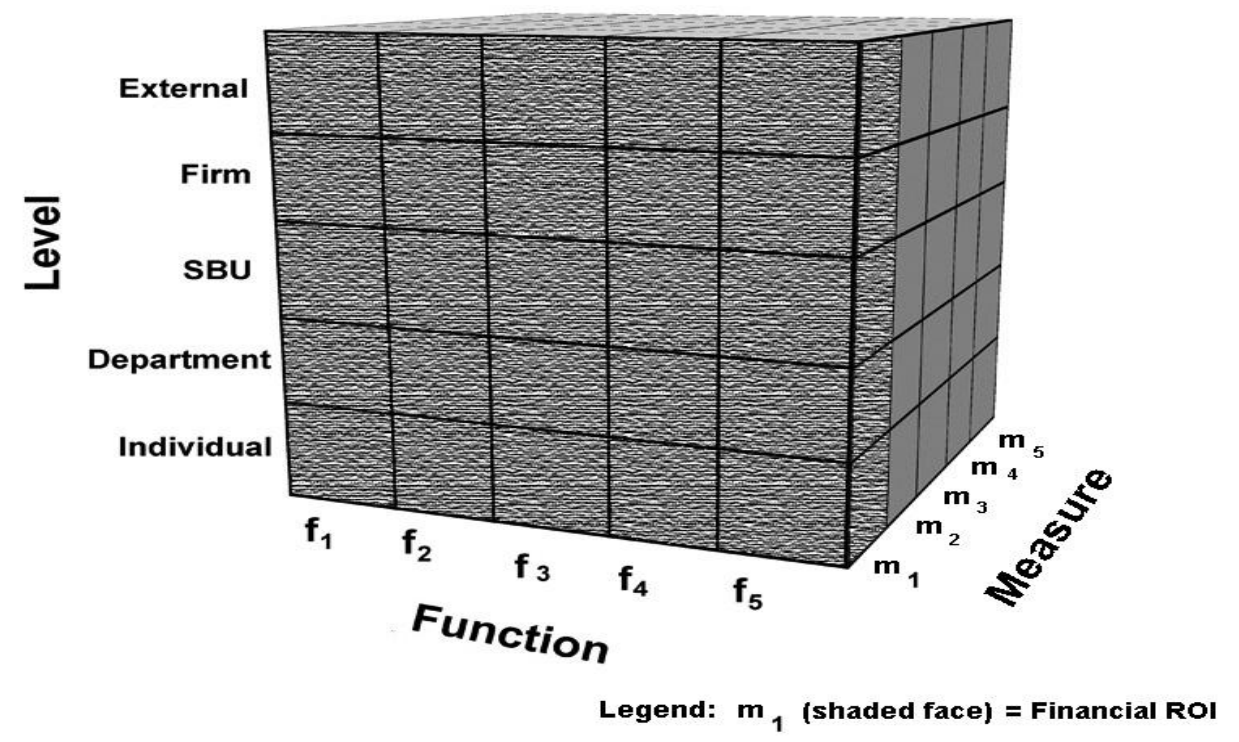

The third and final (and perhaps most critical) dimension of our conceptual framework involves the specific SM measures - depicted along the right side of our 3D cube in figure 2. Lots of discussions have taken place here. As noted earlier, many have weighed in about the merits of direct measurement, pure financial measurement, long term vs. short term measures, and non-measurable variables. The ROI "measurement unit" is obviously complex and should be carefully understood for what it is and is not. This is an area where much additional effort will likely be put forth as it is the core of the ROI discussion - and it is the end of the line as far as the financial budget decision makers are concerned. You either make the grade here or you don't get the budget to continue your SM marketing programs. All that being said, however, our contention is that the larger 3D framework is the right backdrop against which the measurement units must be considered.

From the authors' view, it is critical to understand (and distinguish between) financial ROI measures and non-financial ROI measures... and how each plays a role in ultimately proving, or not proving, the worth of a given SM endeavor. As was discussed above, several academic and industry experts have made this point in some form or another. Again, looking at the right side of our 3D model in Figure 2, one can see the metrics layer of our model. At the very front of the right side of the model is the only pure measure of SM ROI - measured directly in financial currency and calculated by subtracting the cost of a SM investment from the proceeds received from that investment, divided by that same investment cost. As you go back further on the right side of the cube, many other measures can be taken, but they are not ROI. They are indirect, non-financial measures. The further back the metric is from financial ROI, the less likely they are to be converted to an ROI metric in the near future. It should be noted that many, if not most of these metrics could eventually be converted to financial ROI... when they convert to a unit (like sales, cost savings, etc) that is measurable in financial currency. Taking the model a bit further in sophisticated companies, one might even develop a kind of SM forecasting model (based on historical data analysis) that shows the timing and magnitude of likely metrics conversion to a financial metric. Many companies, conceptually, do this now where they use a model that converts customer letters of intent (very indirect measure) and bookings (less indirect) to forecast ultimate revenues (direct) at various points in the future.

Table 2 depicts typical business examples of the three different "dimensions" of SM programs that have been alluded to in our 3D framework discussion. 
Table 2: Example Social Media Measures By Unit Of Analysis

\begin{tabular}{|c|c|c|c|}
\hline Level & Function & Social Media Tool & Measure \\
\hline \multicolumn{4}{|l|}{ External } \\
\hline Industry & $\begin{array}{l}\text { Sales; brand awareness - } \\
\text { dairy industry }\end{array}$ & Industry blog & Sales; website visits \\
\hline Competitor & $\begin{array}{l}\text { Advertising - } \\
\text { automotive }\end{array}$ & LinkedIn, Youtube, Twitter & $\begin{array}{l}\text { Cost savings; sales; market } \\
\text { share; \# views }\end{array}$ \\
\hline Regulator & $\begin{array}{l}\text { Financial consumer protection- } \\
\text { credit card }\end{array}$ & Youtube; Twitter & $\begin{array}{l}\text { Cost savings; \# fraud claims; } \\
\text { views }\end{array}$ \\
\hline \multicolumn{4}{|l|}{ Internal } \\
\hline Corporate & $\begin{array}{l}\text { Logistics - } \\
\text { holiday reminder ads }\end{array}$ & Facebook; Youtube; Flickr & $\begin{array}{l}\text { Cost savings; seasonal } \\
\text { revenues; brand equity }\end{array}$ \\
\hline \multicolumn{4}{|l|}{$S B U$} \\
\hline Product Division & $\begin{array}{l}\text { Product launch- } \\
\text { technology (online only) }\end{array}$ & Youtube; Facebook & $\begin{array}{l}\text { Cost saved; revenues; \# } \\
\text { posts; \# views }\end{array}$ \\
\hline Region & $\begin{array}{l}\text { Product development - } \\
\text { regional salsa recipe }\end{array}$ & Crowdsourcing website & $\begin{array}{l}\text { Cost saved; revenues; \# ideas } \\
\text { generated }\end{array}$ \\
\hline Market Segment & $\begin{array}{l}\text { Retirement planning - } \\
\text { baby boomers }\end{array}$ & Insurance Webinar & $\begin{array}{l}\text { Cost saved; revenues; \# } \\
\text { attendees; \# Facebook votes }\end{array}$ \\
\hline Technology & $\begin{array}{l}\text { Training - } \\
\text { new computer }\end{array}$ & $\begin{array}{l}\text { Youtube; Facebook; } \\
\text { Corporate Blog }\end{array}$ & $\begin{array}{l}\text { Cost saved; free publicity; \# } \\
\text { likes }\end{array}$ \\
\hline \multicolumn{4}{|l|}{ Department } \\
\hline Human Resources & $\begin{array}{l}\text { Recruiting, hiring - } \\
\text { nursing }\end{array}$ & LinkedIn; Facebook, Twitter & Cost saved; publicity \\
\hline Finance & $\begin{array}{l}\text { Accounts receivable - } \\
\text { healthcare collections }\end{array}$ & Facebook; Twitter; Ebay & $\begin{array}{l}\text { Revenue collected; cost } \\
\text { saved; \# disputes }\end{array}$ \\
\hline Marketing & $\begin{array}{l}\text { Advertising - } \\
\text { two for one meals }\end{array}$ & Foursquare; Urban Spoon & $\begin{array}{l}\text { Revenue; cost saved; \# } \\
\text { views }\end{array}$ \\
\hline Information Tech. & $\begin{array}{l}\text { Product repair- } \\
\text { consumer product }\end{array}$ & Youtube; Flickr; Blogs & $\begin{array}{l}\text { Cost saved; revenue; } \\
\text { \# complaints }\end{array}$ \\
\hline Customer Service & $\begin{array}{l}\text { Customer relationship management - } \\
\text { airline }\end{array}$ & $\begin{array}{l}\text { Flyertalk, Facebook, } \\
\text { Twitter; Blogs }\end{array}$ & $\begin{array}{l}\text { Cost savings; revenue; brand } \\
\text { image; \# views }\end{array}$ \\
\hline \multicolumn{4}{|l|}{ Individual } \\
\hline Product & $\begin{array}{l}\text { Consumer product design- } \\
\text { product designer }\end{array}$ & $\begin{array}{l}\text { Twitter; Facebook; } \\
\text { LinkedIn, Blogs }\end{array}$ & $\begin{array}{l}\text { Cost saved; \# design ideas; } \\
\text { brand image }\end{array}$ \\
\hline Program & $\begin{array}{l}\text { Healthcare awareness - } \\
\text { cervical cancer program }\end{array}$ & $\begin{array}{l}\text { Youtube; Flickr; Facebook; } \\
\text { Blogs }\end{array}$ & $\begin{array}{l}\text { Cost saved; lives saved; } \\
\text { brand image; \# views }\end{array}$ \\
\hline Person & $\begin{array}{l}\text { Image management - } \\
\text { political campaign }\end{array}$ & $\begin{array}{l}\text { Twitter; Facebook; } \\
\text { LinkedIn; Blogs }\end{array}$ & $\begin{array}{l}\text { Contributions; cost saved; \# } \\
\text { votes; \# views }\end{array}$ \\
\hline
\end{tabular}

Traditional advertising media have typically cared about, and attempted to maximize, three key measures of performance - Frequency, Reach, and Yield. With the advent of SM, the game has gotten more complicated, faster, actively involves more players, AND has raised the stakes. Business entities must now begin to think about a

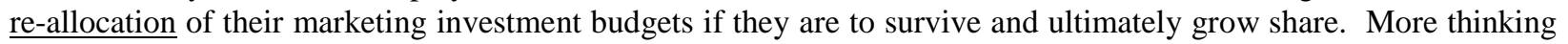
and research need to be done in this area.

\section{Social Media Business Processes}

SM programs, projects, or initiatives should follow these steps:

- $\quad$ Review and align with industry or corporate goals. To be successful, any SM project must be aligned with some higher order entity or goal. That could be a dairy industry goal of increasing the consumption of milk, a healthcare goal of increasing the awareness of gynecological cancers, or an automotive dealerships goal of increasing service revenues. Step one answers the question: "If the SM project is successful what entity will benefit and how can the benefit be tracked to the higher entity's measurable goals?" 
- Develop clear program goals, objectives, and metrics. Each SM program or project must have clearly articulated goals and objectives. Goals, for our purposes here, are higher order strategic measures and objectives are subordinate activities that must be done to achieve the higher order goals. Metrics provide qualitative evidence of achievement. For example: Goal - Become one of the most celebrated Thai restaurants in the tri-state valley using social media. Objectives - (1) Accelerate the number of favorable impressions from our restaurant website. (2) Achieve recognition from the blogs of top food critics in the area (3) Increase customer visits using Urbanspoon platform. Metrics - Looking at the 3 objectives above, the following possible metrics jump to mind: (1) \# hits to website; \# likes (2) \# favorable references from food critics blog (3) Number of QR discount codes read from mobile devices. Some of these measures are purely financial (i.e. QR discount at sale) while others (i.e. \#hits to website) might, at the moment, be pretty far removed from a financial ROI calculation.

- $\quad$ Communicate program goals, measures, and timelines. All those associated with the SM program or project (directly or indirectly) should be fully aware of what it is trying to accomplish, how it will be known if the program is successful, and when the program will roll out and come to a conclusion.

- Roll out the program. Execute the SM plan. Make sure that actions are implemented, and that due dates and quality deliverables are achieved.

- Monitor and track metrics. Review SM business process metrics regularly (i.e. daily, weekly, monthly) as you would any other key business process metrics. Identify gaps between actual metrics and target metrics; identify potential corrective actions. Identify any issues in metrics collection or calculation.

- Make adjustments. Some SM programs (because of the difference between actual and targeted results metrics) may need tweaking or tuning after launch...increasing QR code discount rates, adding "specials" to a list of products or services offered; increasing (or decreasing) the frequency of a technical blog, etc. At one formerly struggling sushi restaurant, a restaurant.com coupon was eliminated because the overwhelming response to the online ad blitzes (which drew people to purchase and download the discount coupons) - had caused business to skyrocket.

- Continuously improve programs, processes, metrics. In the spirit of kaizen, one should always look to improve the efficiency and effectiveness of SM programs. Benchmarks should be against past internal programs and, where possible, against external sources. No matter how good the results, improvement is always possible (and desirable).

\section{Social Media Program Guidelines and Principles}

SM usage, as practiced by an individual or as governed by a corporate or institutional entity, can benefit from guidelines and principles. There are many suggestions offered in the public press and some in the more disciplined work of Olivier Blanchard (Blanchard, 2011). Below is a brief list adapted from these works:

- $\quad$ Transparency - Where possible, state who you are and who you represent - be clear about any vested interest that you may have. Never give the impression that you are providing false or misrepresented facts; product or service claims should be substantiated.

- Responsibility/Anti-Defamation - Exercise good judgment in creating social media. Be respectful, use good taste, and common sense; avoid producing spam and off-topic, self-serving comments. Stick to your area of expertise and strive to provide unique, individual perspectives on non-confidential company or industry activities. When discussing competition, get facts straight, behave diplomatically, and use prudent judgment while avoiding disparaging remarks. Never comment on anything related to legal matters, litigation, or any parties you (or your company) may be in litigation with. Know the difference between an opinion and a false statement.

- Confidentiality, Copyrights, and Non-disclosure - It's best to ask permission to publish information that is meant to be private or internal to a company. Ensure that efforts to be transparent don't violate the corporations' privacy, confidentiality, and legal guidelines for external communications. Always give others credit for their work. 
- Know Your Audience - When you're blogging, tweeting, connecting on LinkedIn or otherwise engaged in SM channels, remember that your readers include current clients, potential clients, as well as current/past/future employees. You must clearly understand what your audience wants, engage them, and then be careful not to alienate or antagonize them along the way.

- Build a Community - The idea behind community is that you can support others, and they can support you or your company. Provide a platform where prospects/users/customers are comfortable sharing, networking, giving or receiving help. Be the go-to place where your audience will flock to when they want to engage others who share their passion - whatever that is.

- Value Add - SM efforts will return dividends to the extent that they provide some kind of value to readers, followers, customers, fans, or prospects. SM platforms can help them find things at a better price, teach them how to do things correctly, allow them to give creative inputs that help re-design products, help them find information quickly, etc. In short, give them a significant reason to engage with you and/or your company. Do this and you will reap the rewards.

- $\quad$ Training - Learn about the basics, benchmark with the best, or simply keep up with the latest SM platforms, analytics, and challenges. No matter what the level of expertise, online or in person training can accelerate learning, save time, and make the user more efficient and effective when it comes to SM adoption and usage.

\section{CONCLUSION}

The development and proliferation of SM tools and platforms is now a matter of record. More and more people are using them to market, to research, to connect, to advise, to purchase, to hire, to qualify, to complain - just to name a few. SM is exploding both inside and outside of corporations and institutions - globally. They are used for a plethora of functions across and within a wide variety of business (and non-business) departments. Despite all of this growth, however, there is still only a small percent of advertising dollars being spent on social media. A key part of the reason for this is because it has been difficult to measure the potential/actual return on advertising investment (spend). Those holding the purse strings need to be convinced that the SM investments will yield top and/or bottom line results - hopefully sooner rather than later. SM ROI measurement has been approached (in both the popular and academic literature) from a variety of different angles and many have given their views of what it should, and shouldn't be. This paper has attempted to proffer a 3D conceptual model which considers the complexities of SM measurement, and posits an integrative "unit of analysis" approach to understanding the current state of disarray, along with a practical set of business process steps and guidelines for implementing SM programs/projects.

\section{FUTURE RESEARCH}

While the authors feel that the 3D model presented is reasonably comprehensive and can help make sense of the vagaries of SM measurement, others should weigh in with their consenting or dissenting views, opinions, and data. There is clearly a strong need for research to validate/test our model or posit their own (i.e. similar to Pooja et al., 2012). In particular, it would be very interesting to see quantitative, mathematical models that demonstrate some form of predictive link between various kinds of SM metrics and the ultimate ROI top/bottom line financial measurement that has become the "holy grail". The authors are currently thinking about a follow up article that will suggest a new ROI - a "reallocation of (current advertising) investment" as an alternative way to think about the justification of expenditures for SM initiatives.

\section{AUTHOR INFORMATION}

Dr. David M. Gilfoil earned his Ph.D. at Stevens Institute of Technology in Hoboken, NJ in 1983. Currently he is Director of the MBA program at DeSales University in Center Valley, PA. Dr. Gilfoil teaches Marketing, Management, Sales and Sales Management, Business Ethics, and Consumer Behavior. Prior to joining DeSales, he spent over 25 years in the telecom and semiconductor industries and has business experience in 40 countries in North America, South America, Europe, and Asia. E-mail: david.gilfoil@desales.edu (Corresponding author) 
Dr. Charles Jobs earned his Ph.D. from The University of Southern Mississippi in 2006. Currently he is a professor teaching International Marketing and International Business Management at DeSales University in Center Valley, PA. Prior to his academic career, Dr. Jobs was the General Manager of the SITA Business Unit in North America for France Telecom (Orange). He has conducted business in 25 countries and has spent considerable time overseas during his 20+ year career. E-mail: charles.jobs@desales.edu

\section{REFERENCES}

1. Arminen, L. (2010). Using Social Media Strategically for Successful Buzz Marketing, Case: Spin Group. Thesis: Degree Programme in Business Management. Laurea University of Applied Sciences, Finland, May.

2. Arnold, T. (2011). ROI on Social Media. Arts Marketing, Spring, 1-10.

3. Bartholomew, D. (2010, February 25). Relief from your Social Media Angst [Web log post]. Retrieved June 14, 2012, from http://metricsman.wordpress.com/2010/02/25/relief-from-your-social-media-roi-angst/

4. Bartholomew, D. (2010, May 12). The Digitization of Research and Measurement [Web log post]. Retrieved June 14, 2012, from http://metricsman.wordpress.com/2010/05/12/the-digitization-of-researchand-measurement/

5. Bartholomew, D. (2011, December 30). Social Media Measurement 2011: Five Things to Forget and Five Things to Learn [Web log post]. Retrieved June 14, 2012, from http://metricsman.wordpress.com/2010/12/30/social-media-measurement-2011-five-things-to-forget-andfive-things-to-learn/

6. Bartholomew, D. (2009, June 4). Measuring Influence in Social Media [Web log post]. Retrieved June 14, 2012, from http://metricsman.wordpress.com/2009/06/04/measuring-influence-in-social-media/

7. Bartholomew, D. (2010, July 19). Don't Let the Tool Tail the Measurement Dog [Web log post]. Retrieved June 14, 2012, from http://metricsman.wordpress.com/2010/07/19/dont-let-the-tool-tail-wag-themeasurement-dog/

8. Berger, P. \& Nasr, N. (1998). Customer lifetime value: marketing models and applications. Journal of Interactive Marketing, 12(1), 17-30.

9. Blanchard, O. Oliver Blanchard Basics of Social Media ROI. (2009, August 24). Social Fresh Conference. Slideshare.Net. Retrieved June 14, 2012, from http://www.slideshare.net/thebrandbuilder/olivier-blanchardbasics-of-social-media-roi/

10. Blanchard, O. (2011). Social Media ROI: Managing and Measuring Social Media Efforts in Your Organization. Boston: Pearson Education, Inc.

11. Bragg, S. (2007). Business Ratios and Formulas: A Comprehensive Guide. (pp. 123-144). Hoboken:John Wiley \& Sons, Inc.

12. Bughin, J. \& Chui, M. (2010). Rise of the networked enterprise: Web 2.0 finds its payday, McKinsey Quarterly, December, 1-9. Retrieved May 16, 2011, from http://perseidsoftware.com/Documents/McKinsey_Web20_Dec_2010.pdf

13. Berger P. D., Mathur, P., Black, J. E., Cao, J., \& Weinberg, B. D. (2012). The Impact of Social Media Usage on Consumer Buying Behavior. Advances In Management, 5(1), 14-22.

14. Broom, D., McCann, M., Bromby, M, \& Barlow, A. (2011). Return on Investment: What Literature Exists on the Use of Social Media and ROI? (September 1, 2011). Available at SSRN: http://ssrn.com/abstract=1926900 or http://dx.doi.org/10.2139/ssrn.1926900

15. Campbell, C. (2011, March 25). Social Analytics Tools for Measuring the Impact of Your Social Media Marketing Campaign [Web log post]. Retrieved June 14, 2012, from http://www.lakeshorebranding.com/company/blog/social-analytics-tools-for-measuring-the-impact-ofyour-social-media-marketing-campaign/

16. Constantinides, E., Romero, C.L. \& Gómez, M.A. (2008). Social media: a new frontier for retailers. European Retail Research, 22(1), 1-28.

17. Culnan, M., McHugh, P., \& Zubillaga, J. (2010). How large U.S. companies can use Twitter and other social media to gain business value. MIS Quarterly Executive, 9(4), 243-259. 
18. D'Silva, B., Bhuptani, R., Menon, S., Mittal, K., \& D'Silva, S. (2011). Influence of Social Media Marketing on Brand Choice Behaviour among Youth in India: An Empirical Study. In ICTBM Proceedings.Paper presented at the International Conference on Technology and Business Management, Dubai, 28-30 March (pp.756-763).

19. Di Gangi, P., Wasko, M., \& Hooker, R. (2010). Getting customers' ideas to work for you: Learning from Dell how to succeed with online user innovation communities. MIS Quarterly Executive, 9(4), 213-228.

20. Dorflinger, T. (2011). Social Media Measurement: How to legitimize the effort in online communication. Thesis submitted to the University of Applied Sciences FH Joanneum Graz.

21. Filisko, G. M. (2011). Social Media or Snake Oil. ABA Journal. 97(1), 26-27.

22. Fisher, T. (2009). ROI in social media: A look at the arguments. Database Marketing \& Customer Strategy Management, 16(3), 189-195.

23. Forrester Research. US Interactive Marketing Forecast, 2011 To 2016. http://www.forrester.com/rb/Research/us interactive marketing forecast,_2011_to_2016/

24. Freeman, R. E. (1984). Strategic management: A stakeholder approach. Boston: Pitman.

25. Freeman, R. E., \& Evan, W. M. (1990). Corporate governance: A stakeholder interpretation. The Journal of Behavioral Economics, 19(4), 337-359.

26. Freeman, R. E., \& Gilbert, D. R., Jr. (1987). Managing stakeholder relationships. In S. P. Sethi \& C. M. Falbe (Eds.), Business and society. (pp. 397-423). Lexington: Lexington Books.

27. Gallaugher, J. \& Ransbotham, S. (2010). Social media and customer dialog management at Starbucks. MIS Quarterly Executive, 9(4), 197-212.

28. Gillin, P. (2010). Making the ROI case for social media. B to B, 95(9), 8.

29. Goldsmith, R. E. (2006). Electronic Word-of-Mouth. In Khosrow-Pour, M. (Ed.), Encyclopedia of ECommerce, E-Government and Mobile Commerce, (Vol. 1, pp. 408-412). Hershey:Idea Group Publishing, Inc..

30. Hall, L. \& Hume, C. (2011). Why Numbers, Invites and Visits are not Enough: Evaluating the User Experience in Social Eco-Systems. In ThinkMind. Paper presented at SOTICS 2011. The First international conference on Social Eco-Informatics, Barcelona, Spain, 23-29 October (pp. 8-13). Iaria.

31. Hartline, J.D., Mirrokni, V.S., \& Sundararajan, M. (2008). Optimal marketing strategies over social networks. Proceedings of the 17th International Conference on World Wide Web, 189-198. doi:10.1145/1367497.1367524

32. Hennig-Thurau, T., Gwinner, K.P., Walsh, G., \& Gremle, D.D. (2004). Electronic Word-of-Mouth via Consumer-opinion Platforms: What Motivates Consumers to Articulate Themselves on the Internet? Journal of Interactive Marketing, 18(1), 38-52.

33. Hoffman, D. \& Fodor, M. (2010). Can You Measure the ROI of Your Social Media Marketing? MIT Sloan Management Review. 52(1), 41-49.

34. Hutton, G. \& Fosdik, M. (2011, December). The globalization of social media: consumer relationships with brands evolve in the digital space. Journal of Advertising Research, 564-570.

35. Jalilvand, M. R., Esfanani, S. S., \& Samiei, N. (2011). Electronic Word-of-Mouth: Challenges and Opportunities. Procedia Computer Science, 3, 42-46.

36. Jansen, B., Zhang, M., Sobel, K., \& Chowdury, A. (2009). Twitter Power: Tweets as Electronic Word of Mouth. Journal of the American Society for Information Science and Technology, 60(11), 2169-2188.

37. Jobs, C. (2012). A Comparative Analysis of the Adoption Rates of Social Networking and Micro-blogging Between Industrialized and Developing Nations. Journal of International Business Research, 11(1).

38. Jobs, C. \& Gilfoil, D. (2012). Less is More for Online MARCOM in Emerging Markets: Linking Hofstede's Cultural Dimensions and Higher Relative Preferences for Microblogging in Developing Nations. Academy of Marketing Studies Journal, 16(2), 79-96.

39. Kaplan, R. \& Norton, D. (1992). The Balanced Scorecard. Measures That Drive Performance. Harvard Business Review, 1(1).

40. Kaplan, R. \& Norton, D. (1996). The Balanced Scorecard. Translating Strategy into Action. Boston:Harvard Business Review Press.

41. Kaplan, R, \& Norton, D. (2001). The Strategy-Focused Organization. How Balanced Scorecard Companies Thrive in the New Business Environment. Boston: Harvard Business School Press.

42. Kane, G., Majchrzak, A., \& Ives, B. (2010). Editors comments. MIS Quarterly Executive, 9(4), iii-iv. 
43. Kaske, F., Kugler, M., \& Smolnik, S. (2012). Return on Investment in Social Media - Does the Hype Pay Off? Towards an Assessment of the Profitability of Social Media in Organizations. In IEEE Computer Society 2012. Paper presented at The 45th Hawaii International Conference on System Sciences, Grand Wailea, Maui, 4-7 January (pp. 3898-3907).

44. Lenskold, J. (2003). Marketing ROI: The path to campaign, customer, and corporate profitability, New York: McGraw-Hill.

45. Leskovec, J., Adamic, L.A. \& Huberman, B. A. (2007). The dynamics of viral marketing. ACM Transactions on the Web, l(1), 5.

46. Levy, J. R. (2010). Facebook Marketing - Designing Your Next Marketing Campaign. Boston:Pearson Education, Inc.

47. Mangiuc, D. M. (2009). Measuring Web 2.0 Efficiency. Annales Universitatis Apulensis: Series Oeconomica. 11(1), 74-87.

48. McLellan, D. (2010, November 5). Do You Have Confidence in Your Social Media Strategy? [Web log post]. Retrieved June 14, 2012, from http://socialmediatoday.com/drewmclellan/232153/do-you-haveconfidence-your-social-media-strategy

49. Murdough, C. (2009). Social Media Measurement: It's Not Impossible. Journal of Interactive Advertising. 10(1), 94- 99.

50. Nair, M. (2011). Understanding and measuring the value of social media. Journal of Corporate Accounting \& Finance. 22(3), 45-51.

51. New York Times (2010, February 4). Sun's Chief Executive Tweets His Resignation by Ashlee Vance [Web $\log$ post]. Retrieved June 13, 2012, from http://bits.blogs.nytimes.com/2010/02/04/suns-chief-executivetweets-his-resignation/

52. Parise, S. \& Guinan, P. J. (2008). Marketing using Web 2.0. In IEEE Computer Society 2008. Paper presented at The 41st Hawaii International Conference on System Sciences, Waikoloa, Big Island, 7-10 January (p. 281).

53. Pearson, R. (2010, December 13). The Social Business Scorecard IV or ROI Made Easy [Web log post]. Retrieved May 17, 2011, from http://theparallaxview.com/2010/12/social-business-scorecard-iv-roi-easy/

54. Piskorski, M., \& McCall, T. (2010). Vision Statement: Mapping the Social Internet. Harvard Business Review, 88 (7-8).

55. Powell, G., Groves, S., \& Dimos, J. (2011). ROI of Social Media: How to Improve the Return on Your Social Marketing Investment. Singapore: John Wiley \& Sons (Asia).

56. Pooja, M., Black, J., Cao, J., Berger, P., \& Weinberg, B. (2012). The impact of social media usage on consumer buying behavior. Advances in Management. 5(Jan), 14-22.

57. Ray, A. (2010, July 19). The ROI Of Social Media Marketing: More Than Dollars And Cents [Web log post]. Retrieved June 14, 2012, from http://blogs.forrester.com/augie_ray/10-07-19-

roi_social_media_marketing_more_dollars_and_cents

58. Rust, R., Lemon, K., \& Zeithaml, V. (2004). Return on marketing: Using customer equity to focus marketing strategy. Journal of Marketing, 68(1), 109-127.

59. Sheridan, J. (2010, January 27). Social Media ROI - Using Balanced Scorecard Principles [Web log post]. Retrieved May 17, 2011, from http://www.socialmedia404.com/?p=1393

60. Scott, D. M. The New Rules of Marketing and PR: How to Use Social Media, Blogs, News Releases, Online Video, and Viral Marketing to Reach Buyers Directly, Hoboken:John Wiley \& Sons, Inc.

61. Solis, B. (2008). The Essential Guide to Social Media - A Free eBook. Retrieved from http://www.briansolis.com/2008/06/essential-guide-to-social-media-free/

62. Solis, B.: Engage: The Complete Guide for Brands and Businesses to Build, Cultivate and Measure Success in the New Web. Hoboken:John Wiley \& Sons, Inc.

63. Subramani, M. \& Rajagopalan, B. (2003). Knowledge-Sharing and Influence in Online Social Networks via Viral Marketing. Communications of the ACM, 46(12), 300-307.

64. Trochim, W. (2001). Research Methods Knowledge Base. Atomic Dog Publications.

65. Turner, J. (2010, November 5). How To: Calculate the ROI of Your Social Media Campaign [Web log post]. Retrieved May 17, 2011, from http://mashable.com/2010/11/05/calculate-roi-social-media/

66. Van der Lans, R., Van Bruggen, G., Eliashberg, J., \& Wierenga, B. (2010). A Viral Branching Model for Predicting the Spread of Electronic Word of Mouth. Marketing Science, 29, 348-365. 
67. Weber, L. (2009). Marketing to the Social Web: How Digital Customer Communities Build Your Business, Hoboken: John Wiley\& Sons, Inc.

68. Zheng, D. (2011, April). Measuring ROI of Social Media Efforts [Web log post]. Retrieved June 25, 2012, from http://www.radian6.com/blog/2011/04/social-2011-measuring-roi-of-social-media-efforts/

69. Zheng, D., et al. (2010). Social Media Analytics and Intelligence, IEEE Intelligent Systems. 25(6), 13.

70. Zilkmund, W., Babin, B., Carr, J., \& Griffin, M. (2010). Business Research Methods. Mason: Cengage Learning, Inc. 


\section{NOTES}

